\title{
Life, Death and Silencing: Legal Discourses on Filicide
}

\author{
Waldriane Nascimento da Silva \\ Master's in Public Security, \\ Citizenship and Human Rights from the State University of Amazonas (UEA); \\ Collaborator in the Extension Project \\ "Health as way of freedom for women at the Female Penitentiary of Manaus" \\ Social Worker at the Federal University of Amazonas (UFAM) \\ Rua Benjamin, 57, Cidade de Deus - Código Postal 69099-815 \\ Manaus, Amazonas, Brazil
}

Izaura Rodrigues Nascimento

$\mathrm{PhD}$ in International Relations and Regional Development (UnB UFRR / FLACSO);

Professor of the Postgraduate Program in Public Security

Citizenship and Human Rights at the Amazonas State University (UEA)

Rua Castelo Branco, 504, Cachoeirinha - Código Postal 69065-010

Manaus, Amazonas, Brazil

André Luiz Machado das Neves

$\mathrm{PhD}$ in Collective Health (Human and Social Sciences in Health)

Institute of Social Medicine

Rio de Janeiro State University (IMS/UERJ).

Professor of the Postgraduate Program in Public Security,

Citizenship and Human Rights at the Amazonas State University (UEA)

Rua Castelo Branco, 504, Cachoeirinha - Código Postal 69065-010

Manaus, Amazonas, Brazil

\begin{abstract}
This article ${ }^{l}$ aims to shed light on the discourses produced by people of the legal field, who are directly involved in the judgment of crimes characterized as filicides, and seeks to analyze them in the light of Foucault's discourse analysis. This is a qualitative study, developed through bibliographic and documentary research, with systematic examination of judicial processes in res judicata, from 2010 to 2015. The main results show that the discursive construction of the legal field is guided by the vision of a harmonized family, homogenizing police practices that reduce crime to the procedural number, operating the silencing of victims, during life and after death.
\end{abstract}

Keywords: Discourse, Power, Silence, Violence.

\section{Introduction}

Understanding interfamily violence is a complex task, however it is an important and necessary job for those who wish to build coping strategies for a problem that is becoming more and more common every day. During this study, carried out jointly by three renowned public universities, which focused on intrafamily homicides in the northern region of Brazil, concerns arose about the crimes involving parents who killed their children, otherwise known as filicide. These concerns became the object of investigation in a dissertation study of which this article is the result.

Immersion in the world of research is a rich experience, in which the construction of the methodological path is figuratively a theatrical play, where researcher develops a role as both actor and spectator. The object of research appears in each scene, but never shows itself completely, it is up to the researcher-actor-spectator to discover it gradually through the successive approaches necessary for its construction and apprehension.

\footnotetext{
${ }^{1}$ We are grateful for the financial support of the Amazonas Research Support Foundation (FAPEAM) through the Support Program for the Publication of Scientific Articles (PAPAC - Call 005/2019).
} 
The dissertation study from which this article originates is a qualitative research, which combines bibliographic and documentary research, the latter through systematic examination of judicial processes involving homicides perpetrated by parents against their children (considered family models in which the role of father or mother can be played by other people who are not necessarily blood relatives), which were tried and sentenced by the Amazonas State Court in the period from 2010 to 2015 . Dealing with homicides perpetrated by parents against children is a complex and difficult, however instigating theme, especially if one considers the fact that it is also a social taboo. In addition, two obstacles in the execution of the research required significant efforts. Firstly, the need to overcome the theoretical gap involving the research theme and make theoretical and methodological choices, and secondly, the need to overcome the barriers imposed on the researcher regarding bureaucratic access to data and the access authorizations necessary for the study.

The data collection environment functioned as a kind of thermometer about how the judicial discourses on filicides are constructed, and clarify that they transcend texts and discourses, transfiguring themselves into social practices, in which behavior (ways of dressing, behaving, communicating) reveal the logic of power inherent in the legal field. The existing differentiation between those who have or do not have the legal competence so important for accessing the judicial area, as well as the prevailing rituals in it, require not only a specific knowledge, but also a certain way of dressing and behaving so that one can be accepted. During the data collection, it was necessary to a certain extent to yield to the typical game of the legal field. The use of formal clothing, interinstitutional identification (badge), and the type of language used for communication were essential elements to achieve the objective. Power, as a diffuse element that is spread by the social whole, was also an element seen in these incursions, especially the successive explanations requested in almost all the visits carried out. These explanations functioned as a kind of "test" sometimes to assess the knowledge and relevance of the research, sometimes to affirm the supposed position of superiority of certain officials in regards to access to the data.

Given the difficulties encountered, the concern regarding the theme and the academic and social relevance of the research motivated the researcher to its successful conclusion. This was especially supported by the understanding of research as social and political action, which requires ethical commitment and, moreover, that the socialization of the results is an indispensable factor for the advancement of science. That said, this paper aims to present the nuances of the discourse produced by those who work in the legal field in the Amazonas state and are directly involved in the trials of crimes that are characterized as filicides. These trails were analyzed in the light of Foucauldian discourse analysis and seek to reflect on their social implications.

\section{Discourse and the legal field}

Discourse is a place full of struggles, and its construction is full of power relations, through which truths are established. Therefore, understanding the production of discourses is an indispensable condition for understanding the effects of these discursive practices in society.

In the treatise "The Archaeology of Knowledge", Foucault (2008, p. 61) explains that:

"Discourse is not the manifestation of a subject who thinks, Who knows and who speaks [...] it is a space of exteriority, in which distinct places develop [...] it is not by recourse to a transcendental subject nor by recourse to a psychological subjectivity that one should define the regime of their enunciations."

The author explains that such a description is "precisely an abandonment of the history of ideas, systematic refusal of their postulates and their procedures, an attempt to make a history entirely different from what men have said" (FOUCAULT, 2008, p.156). This means that it is not just a tool to interpret what is said or not said, but to know if what is said can be changed and how it can be done.

Continuing his explanation, the author asserts that:

"The archaeology seeks to define not the thoughts, representations, images, themes, obsessions that are hidden or manifested in discourses, but the discourses themselves, as practices that obey rules. It does not treat discourse as a document, as a sign of something else, as an element that should be transparent, but whose importunate opacity must often be crossed in order to rediscover, in short, where the part remains, the depth of the essential; it addresses discourse in its own volume, as a monument. This is not an interpretative discipline: it does not seek a more hidden "other discourse". It refuses to be allegorical. [...] It does not seek to reconstruct what could be thought, desired, aimed at, experienced, desired by men at the very moment in which they uttered the discourse" (p. 157).

Thus, discourse refuses analysis purely and simply from grammatical assumptions or how the discourses were constructed and what meanings the people who proffered it gave it, in this way the speeches must be revealed through themselves, as an element of construction of the individual himself and social practices. The author asserts that even in two identical enunciations and with identical formations, this fact does not authorize us to identify them in absolute terms, since if the discourses are, and are made as, social practices, they are loaded with their own meanings, particular to the contexts in which they are proffered. 
In this sense, the legal field becomes a particular field of discourses, which in turn establishes it as the place of competition by exclusive power over legal knowledge, in which the professionals who have social and technical competence are faced. In other words, the interpretative capacity of texts that consecrate the legitimate views of what is said as being justice. Bourdieu (2012, p. 579) explains that the legal field begins to be constructed from the sixteenth century onwards, as a space in which "people fight about even what is a collective monopoly of who is in that space [...] it is a place where it is constantly about knowing who is legitimately part of the space and what it takes to participate in that space."

For the author, legal consequences only work because from a very early age it was seen as a field. An example that illustrates this statement is the fact that in this space the hierarchies of universities that teach law are clarified. In the legal field, legitimation, reproduction and the relationship between the professionals that operate in it are directly connected with the accumulation of scientific and intellectual capital and, consequently, the positions occupied by them. In this sense, it can be said that there is competition between professionals for access to legal means and for their rationalization, in order to try to make the legal norms become independent of the relations of force ratified and consecrated. The legal text is permeated by a kind of game of struggles, since its reading is a form of appropriation of the symbolic force present in it and is still in a state of power. However, it must be clarified that the linguistic aspects and processes that belong to legal language retain in themselves the production of some effects, such as neutralization effects through passive and impersonal phrases, and universalization, when using verbs in the third person of the singular.

However, Foucault (2008, p. 164) asserts that:

"We can find identical verbal performances from the point of view of grammar (vocabulary, syntax and, in general, language); which are equally identical from the point of view of logic (propositional structure, or deductive system in which it is situated); but which are enunciatively different."

The elaboration of a body of well-defined rules and procedures, which aims to be universal together with society, as defined by Bourdieu (2010), is the product of the division of labor that results from the competition of competences between the different professionals that make up the legal field. It can be inferred that the laws and their practical content are the results of symbolic struggles among professionals endowed with technical and social skills, able to mobilize, albeit unevenly, the resources available to elaborate these rules, as well as their use as a weapon to assert their positions within these spaces of symbolic struggle.

Bourdieu (2012, p. 571) explains that:

"In order for there to be a struggle in a field there must be agreements on the grounds of disagreement, on the legitimate and legitimately used weapons in the struggle, on the very criteria of triumph, which makes it possible to speak apparently of a culture. But all these instruments, which make the consensus, substantiate the consensus for dissent."

Thus, the judicial space presupposes a boundary between two groups of actors, i.e., those prepared for the use of any theoretical framework and linguistic means, and those who do not have this technical and social preparation, or rather, the "unprepared". This boundary marks the separation between experts from the so-called justiciable, that is, those who will become customers. In the judicial space, the judicial verdict is constructed, which for Bourdieu (2012), is similar to a kind of logical synthesis that is the result of antagonistic theses and has its effectiveness revealed through different fields, which are legal, scientific and political. This requires the understanding that the discourses and propositions of professionals are made from the position he occupies, in other words, from where this subject "speaks". Hence the importance of his titles and knowledge accumulated within this specific field, the latter determines the relationship between professionals and their legitimation. When entering the legal field, the subjects in conflicts accept that their dissent is resolved through a model that abdicates physical force or elementary forms of symbolic violence, such as insults, slander, etc.

Therefore, the legal field represents the monopoly of professionals in regards to the production, marketing and distribution of legal services, which reduces those who renounce the management of their conflicts to clients. Legal competence is a kind of specific power that allows access to the legal field, as well as the determination of important issues. This judicial power is responsible for the manifestation of verdicts and the sovereign view of the State. The latter, named by Bourdieu (2012, p.34) as "administrative field or field of public function", one of the power field, which is defined by the possession of physical violence and symbolic legitimacy. The State represents one of the principles of public order, and it is widely used by jurists. Although it is not reduced to politics, it is founded on consent, therefore, it evidences a kind of "unconscious symbolic form" that no one questions, explains Bourdieu (2012, p.44). Thus, its effectiveness and legitimacy, guaranteed through its symbolic authority, sends the community an illusory idea of consensus. The laws and court judgments are examples of this, because even though the interested parties disagree, when entering the judicial field they abdicated from the right to arbitrate their conflicts passing this right to experts. 
The rights this time become "a form of symbolic power, par excellence, in the creation of appointments and nominees", which by its force produces effects. Law is the product of the social world, and at the same time it produces the social world. (BOURDIEU, 2012, p.237).

The law and power relations present in the legal field are responsible and act directly solving and constructing problems, producing transformations of certain views on these problems in society. According to Sckell (2016, p. 165), "Law and society influence each other in a reciprocal and simultaneous way. On the one hand, law is an active discourse that can produce effects and creates the social world; on the other hand, it is also created by the social world." This reciprocal influence is also an effect of power, since it is spread by society, in everything and in everyone. It is precisely in this relationship between the exercising of powers and the positivity of discourses (knowledge) that Foucault and Bourdieu write their analyses of concrete historical and social phenomena. This is the common ground of these authors, explains Simioni (1999). For both authors, discourse and its effects are socially inscribed, therefore this means that the regime of the production of truth is anchored in history and the regime of production of truth is variable. The author explains that, in Foucault, the notion of power unfolds from networks; for Bourdieu, it is something present in social fields and that it generates recognition. For the former, power is not possession, but is realized in different ways in different places, therefore, the legal field can also be seen as a space in which power is realized. Thus, the statements present and elaborated in the legal field explain in a certain way a kind of domination of a type of knowledge that, for Bourdieu, influences society and is influenced by it. Guided by the understanding of the categories discourse and legal field so far presented, the next item aims to shed light on the discursive constructions elaborated by the professionals of the legal field in the Amazon state regarding the crime of filicide. We explain the main arguments used by the professionals who make up this field and seek to discuss its social implications.

\section{The legal discourse in the Amazonas state called into question}

Lacaz (2009) explains that the construction of a discourse is made by a historically situated subject, the relations established in the discourses directly depend on the social and economic relations put forth. It is precisely for this reason that we need to analyze the discourse produced in the legal field on crimes of filicide. It is imperative to deal with it at its own game (FOUCAULT, 2008. P. 28). In the work The Truth and Judicial Forms, the author explains that the production of discourses is organized and selected from certain procedures the whole time, so that their powers and dangers are mastered, seeking to dodge their fearsome and heavy materiality. Moreover, understanding the discourses and evaluating them is to understand how they could be different. It is necessary to understand the legal field as a space of struggles, where powers and knowledge are present, codes of conduct and its own rituals, which do not escape the procedures of selection and organization, as listed by Foucault.

In the elaboration of legal texts, in the statements presented in the defense and prosecution theses and, even, in the decision of sentences handed down by a judge or instituted through a popular jury, there are values, opinions and knowledge present and everything that makes up and is part of each individual, each professional. This is because, even in the effort to be impartial, it is not possible to undress values and worldviews that are carried. Discourses, in this way, are paths by which contradictions move, which settle like sediment from a certain order, with demarcated goals. Therefore, it is necessary to understand and apprehend it in the game of its instance. The discourses produced in the legal field in the Amazonas state follow a ritualistic pattern that is typical of this field. From the grammatical point of view, it gains strength in the use of elaborate words form Latin and expressions that demarcate a kind of knowledge that is proper to the field.

In addition, the use of adjectives such as "fair" in "fair judge", and "digna" in "digna magistrada" used for the arbitrator of the judicial dispute, reveals that in the legal sector the recognition and appreciation of the positions occupied by the professional are actions of paramount importance. From the logical-argumentative point of view, the statements made explicit in the discursive constructions found tend to favor an idealized vision of a harmonic family, which often ends up blaming individuals. Another important factor directly linked to this is related to the police style practices and the instrumentalization of knowledge from other areas. During the dissertation study, the analysis of the criminal proceedings indicated a pattern of discursive behavior, as can be seen in the excerpts from the discourses in the text of the process. 


\begin{tabular}{|c|c|}
\hline \multicolumn{2}{|r|}{ Excerpts from the legal discourse in the Amazonas state } \\
\hline Professional & Excerpts \\
\hline \multirow{9}{*}{ Prosecutor } & Tough measures to combat delinquency; \\
\hline & Good citizen; \\
\hline & Crime-oriented personality; \\
\hline & Fumus comissi delicti; \\
\hline & Periculum Libertatis; \\
\hline & $\begin{array}{l}{[\ldots] \text { the archaic Penal Code, in its Article } 27 \text {, minors under } 18 \text { years of age, }} \\
\text { cannot be incriminated for the crimes they commit, and are only subject to the } \\
\text { inoperative norms of the Statute of the Child and Adolescent; }\end{array}$ \\
\hline & High degree of dangerousness [...]; \\
\hline & The accused has a personality that is focused on the commission of crimes; \\
\hline & $\begin{array}{l}\text { the maintenance of pretrial detention of the accused, subsisting the need to } \\
\text { maintain the measure to guarantee public order; }\end{array}$ \\
\hline \multirow[t]{6}{*}{ Judge } & Severe response of the State, under penalty of discredit of the judiciary powers; \\
\hline & Fumus comissi delicti; \\
\hline & Periculum Libertatis; \\
\hline & $\begin{array}{l}\text { Preservation of public order; } \\
\text { Integrity, credibility and trust in the institutions; }\end{array}$ \\
\hline & $\begin{array}{l}\text { I do not foresee, at the moment, any threat to the guarantee of public or } \\
\text { economic order }[\ldots] \text { his release in no way will prejudice the progress of the case, } \\
\text { since his presence, henceforth, is a mere faculty that the law assures him; }\end{array}$ \\
\hline & $\begin{array}{l}{[\ldots] \text { dynamics of this crime proves that the probable perpetrators are highly }} \\
\text { dangerous people; }\end{array}$ \\
\hline \multirow{8}{*}{ Defence } & Inexistence of dangerousness; \\
\hline & Moral and physical harm, given the coexistence in the prison environment; \\
\hline & [...]prisons do not correct mistakes, nor improve personalities; \\
\hline & $\begin{array}{l}\text { [...]the accused acted due to strong emotion, seeing his honor and his morale } \\
\text { offended, since his wife always gave grounds to cause him jealousy; }\end{array}$ \\
\hline & $\begin{array}{l}\text { The circumstances were provoked by the victim before the quarrel with the } \\
\text { defendant; }\end{array}$ \\
\hline & $\begin{array}{l}\text { No one will be found guilty until they are in tried and convicted. (Art. } 5 . \\
\text { Subparagraph LVII of the Federal Constitution); }\end{array}$ \\
\hline & $\begin{array}{l}\text { The applicant does not present periculum libertatis and does not threaten public } \\
\text { order, IS A FIRST TIME OFFENDER AND YOUNG, HAS A GOOD } \\
\text { BACKGROUND, HAS A FIXED RESIDENCE [...]; }\end{array}$ \\
\hline & $\begin{array}{l}\text { [...]precautionary measures are an important figure for the awareness of the } \\
\text { offender and a way to lead the defendant towards an honest path; } \\
\text { The roles attributed to punishment in Brazil (and among them, especially the } \\
\text { function of special prevention) have always been characterized as rhetorical. }\end{array}$ \\
\hline
\end{tabular}

Source: documentary analysis of court cases, 2018.

The excerpts of the discourses found and analyzed demonstrate a direct relationship of the discursive construction elaborated in the legal field in the Amazonas state with the punitivist discourse that gains social resonance and has fostered the growth of the Penal State as a way of confronting the multiple expressions of violence. The privileged argumentative logic in the discourses, elaborated within the case text, always refers to the need for tough measures to combat delinquency, indications that certain citizens have a personality focused on crime, the need to safeguard credibility, integrity and trust in judicial institutions. In this sense, issues such as the presumption of innocence and the moral and physical harm of living together in a prison environment that are addressed in the discursive construction of the defense, are disregarded, whether by desire and power of the professionals of the legal field; or because there is an impression that its application denotes a sign of ineffectiveness of the judiciary. At stake is not only the desire for power or the desire for truth, but the demarcation of positions in the field and the recognition among the peers, represented here by the other professionals that make up the legal field. 
The ideal form of justice is little seen in discourses, moreover, it seems that the role of the judiciary is confused with the role of the police. Therefore, police style practices in the judicial field are sedimented as if that was the judicial field's primary function. The homicides committed by parents against their children, which are tried in the legal spheres in the Amazonas state, end up being judged as "regular" homicides, marked by the harmonious family ideal and influenced by the volume of work that tends to homogenize practices in the legal field. In these judgments, it is common to find utterances that reflect a family ideal that socially settled as a conflict-free environment, where love for children appears as a natural feeling to parents and not as a social construction. Killing a child, from this logic of thought, is a heartbreaking crime. Thus, the discourses elaborated in the legal field capture knowledge from other fields, such as the medical-psychiatric, in an authorized way or not, to substantiate the decisions that commonly use expressions such as "violent personality "or" personality oriented to crime" to convict defendants in advance, negating prison in ultima ratio.

The procedural analysis of filicide in the legal field operates as a kind of silencing of a growing expression of intrafamily violence, either by attempting to homogenize the cases or by refusing to recognize the conditions of violence explained in it during the process. The attempt to homogenize the legal action in some way by the volume of work causes the violence suffered by the subjects involved in the processes to be doubly silenced before and after their deaths, ending their lives as just procedural numbers.

\section{Final considerations}

The study and its results indicate that disputes in the legal field offer unequal positions among professionals and that they construct their decisions using the legal-formal framework, but also using aspects linked to moral values, convictions and professional life history. The statements proposed in the decisions explain that the maintenance of order, arguments commonly used to justify and/or ratify the need for imprisonment, extrapolates its visible purposes, a more in-depth analysis reveals other aspects also linked to the need for maintenance of class order. The discourses ratify imprisonment as a punitive element first, even if the Penal Codes indicate it as the last resort. There is a strong and excessive influence of media elements in the conduct of proceedings, including journalistic excerpts composing the case files, even if such facts contradict the recommendations, for example, of the Inter-American Commission on human rights (IACHR).

Almost no discussion occurs regarding the family context of the accused and victims of filicide, in this way, filicide cases are transfigured into numbers. In this sense, the appreciation of an idealized family model is what marks the construction of procedural documents. The attempt to homogenize the cases in the light of norms and laws creates a double silencing of the victims, in life and post-death. The lights on the judicial stage are cast on the disputes for prestige and reaffirmation of those gifted subjects and legal competence and in this game, agents who manifest positions different from the dominant legal order put themselves in a very risky position.

\section{References}

BOURDIEU, Pierre. (2010). A força do direito: elementos para uma nova sociologia do campo jurídico. IN: O poder simbólico. Rio de Janeiro: Bertrand Brasil.

BOURDIEU, Pierre. (2012). Sobre o Estado. Curso do Collège de France 1989-1992. Paris: Raison d'Agir.

FOUCAULT, Michel. (2008) A arqueologia do saber. Tradução de Luiz Felipe Baeta Neves, -7ed. - Rio de Janeiro: Forense Universitária.

LACAZ, Lúcia Maria Marques Gama. (2009). Nos entre-lugares do sujeito e do discurso jornalístico: questões de poder e de subjetividade. (Thesis defended at Instituto de Estudos da Linguagem, Universidade Estadual de Campinas, to obtain a Doctorate degree in Applied Linguistics). Campinas.

SCKELL, Soraya Nour. (2016). Os juristas e o direito em Bourdieu: a conflituosa construção histórica da racionalidade jurídica. In: Tempo Social - Revista de Sociologia da USP, v. 28, n. 1.

SIMIONI, Ana Paula Cavalcanti. (1999). Os efeitos dos discursos: Saber e Poder para Michel Foucault e Pierre Bourdieu. In: Plural, USP, São Paulo, (6 - 103-117). 